\title{
Exploring $\mathrm{N}$-Arylsulfonyl-L-proline Scaffold as a Platform for Potent and Selective $\alpha v \beta 1$ Integrin Inhibitors
}

Nilgun Isik Reed, ${ }^{\dagger}$ You-Zhi Tang, ${ }^{\ddagger}, \|$ Joel McIntosh, ${ }^{\ddagger}$ Yibing Wu, Kathleen S. Molnar, ${ }^{\ddagger}$ Annafelicia Civitavecchia, Dean Sheppard, William F. DeGrado, ${ }^{\dagger}, \S$ and Hyunil Jo*

${ }^{\dagger}$ Department of Medicine, University of California-San Francisco, San Francisco, California 94153, United States

${ }^{\ddagger}$ Department of Pharmaceutical Chemistry, University of California-San Francisco, San Francisco, California 94158, United States

${ }^{\S}$ Cardiovascular Research Institute, University of California-San Francisco, San Francisco, California 94158, United States

"College of Veterinary Medicine, South China Agricultural University, Guangdong 510642, China

Supporting Information

\begin{abstract}
One small molecule inhibitor of $\alpha \mathrm{v} \beta 1$ integrin, c8, shows antifibrotic effects in multiple in vivo mouse models. Here we synthesized c8 analogues and systematically investigate their structure-activity relationships (SAR) in $\alpha \mathrm{v} \beta 1$ integrin inhibition. $N$-Phenylsulfonyl-L-homoproline analogues of c8 maintained excellent potency against $\alpha \mathrm{v} \beta 1$ integrin while retaining good selectivity over other RGD integrins. In addition, 2-aminopyridine or cyclic guanidine analogues were shown to be equally potent to c8. A rigid phenyl linker increased the potency compared to $\mathbf{c 8}$, but the selectivity over other RGD integrins diminished. These results can provide further insights on design of $\alpha \mathrm{v} \beta 1$ integrin inhibitors as antifibrotics.
\end{abstract}

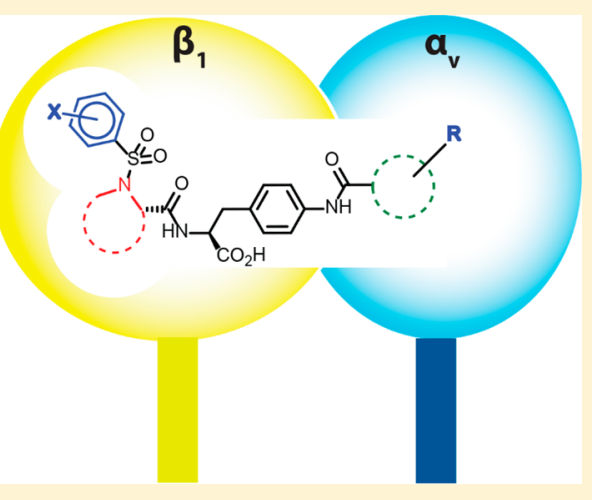

KEYWORDS: Fibrosis, $\alpha v \beta 1$ integrin, phenylsulfonylproline, TGF $\beta$, integrin antagonist

$\mathrm{I}$ ntegrins are transmembrane proteins that mediate cell-cell and cell-extracellular matrix (ECM) interactions. ${ }^{1}$ They exist as heterodimeric proteins consisting of an alpha $(\alpha)$ and beta $(\beta)$ subunit. Multiple isoforms of each subunit have been identified so far with more than half of the integrins containing either the alpha $\mathrm{v}(\alpha \mathrm{v})$ or beta $1(\beta 1)$ subunit. $^{2}$ Due to their crucial biological roles in cell adhesion and proliferation, integrins have been extensively studied as therapeutic targets in cardiovascular diseases as well as cancer chemotherapy, and a few integrin inhibitors have reached the clinic. ${ }^{3}$ Integrins are also involved in the activation of TGF $\beta$, a key cytokine in fibrotic diseases. An antibody against the epithelium-specific $\alpha \mathrm{v} \beta 6$ integrin (STX-100) is in phase II clinical trials for idiopathic pulmonay fibrosis (IPF). ${ }^{4}$ We recently identified a role for another integrin, $\alpha \mathrm{v} \beta 1$, in activating TGF $\beta$ to drive organ fibrosis. ${ }^{5,6}$ A prototype inhibitor, $\mathbf{c 8}$, significantly reduced the fibrotic markers in mouse model for liver and lung fibrosis (Figure 1). These findings suggest that inhibitors of $\alpha \mathrm{v} \beta 1$ integrin could be promising new antifibrotic agents. However, $\alpha \mathrm{v} \beta 1$ integrin has not been widely studied, and little structural information on $\alpha \mathrm{v} \beta 1$ integrin is known. To our knowledge, no other selective and potent $\alpha \mathrm{v} \beta 1$ integrin inhibitors have been developed so far. Thus, we turned our attention to developing antifibrotic agents based upon modification of c8. Structurally, c8 (and its congener c6) mimics the natural ligand tripeptide sequence Arg-Gly-Asp (RGD) by connecting carboxylic acid and guanidinine through a linker. c8 also contains $N$ -

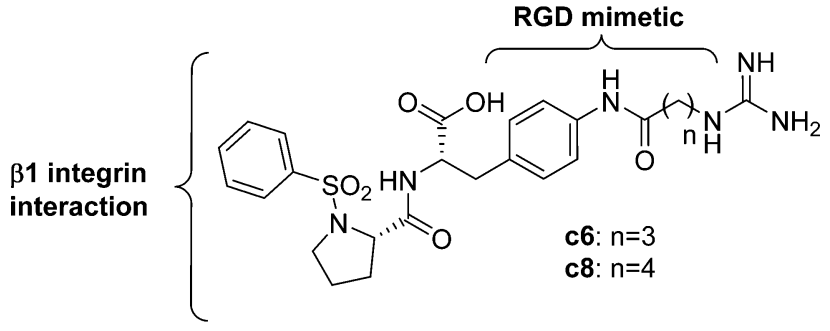

Figure 1. Structure and design principle of integrin inhibitors $\mathbf{c 8}$ and c6.

arylsulfonyl-L-proline scaffold previously shown to confer specificity and potency in inhibition of other $\beta 1$ integrins $(\alpha 2 \beta 1$ and $\alpha 4 \beta 1) .^{7-10}$

Based upon this analysis, we first investigated how the structural modification in $N$-arylsulfonyl-L-prolyl group would influence the potency (Figure 2). It was previously shown that a number of aryl or prolyl analogues in the same $N$-arylsulfonyl-Lprolyl scaffold were identified as potent non-RGD $\beta 1$ integrin inhibitors. ${ }^{8,9,11}$ However, it remains unclear if it holds true in the case of RGD integrin inhibitors like c8. Second, we were

Received: May 11, 2016

Accepted: August 30, 2016

Published: August 30, 2016 


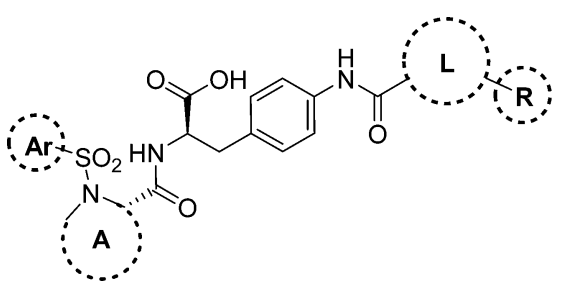

Figure 2. Sites of modification in this study.

interested in SAR of the RGD mimetic moiety since linkers as well as substitution of guanidine basic group could play a significant role in RGD integrin inhibition. ${ }^{12}$

For syntheses of $N$-arylsulfonyl analogues of $\mathbf{c 8}$, we pursued the solid-phase chemistry (Scheme 1). Conventional Fmoc-

Scheme 1. Solid Phase Syntheses of N-Arylsulfonyl-proline Derivatives $^{a}$

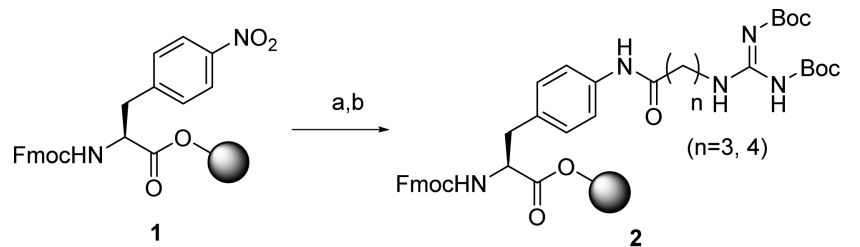<smiles>COC(=O)NC(=NC(=O)Nc1ccc(CC(N)C(=O)OC)cc1)NC(=O)OC(C)(C)C</smiles><smiles>[R]ON1CCC[C@H]1C(=O)N[C@@H](Cc1ccc(NC(=O)[C@H](C)NC(=N)N)cc1)C(=O)O</smiles>

${ }^{a}$ Reagents and conditions: (a) $2 \mathrm{M} \mathrm{SnCl}_{2}, \mathrm{DMF}, 60^{\circ} \mathrm{C}$; (b) $\mathrm{N}, N^{\prime}$-diBoc-guanidino valeric/butanoic acid, HCTU, DIPEA; (c) 20\% 4methylpiperidine, DMF; (d) (i) $\mathrm{N}$-arylsulfonyl-L-proline analogues, HCTU, DIPEA, DMF; (ii) TFA/TIPS $/ \mathrm{H}_{2} \mathrm{O}$ (95:2.5:2.5).

solid phase peptide synthesis strategy was successfully employed to provide Pro-Phe dipeptide scaffold previously. In addition, $\mathrm{N}$-arylsulfonylation of proline on the solid support could facilitate workup and purification. From the commercially available Fmoc-4- $\left(\mathrm{NO}_{2}\right)$-Phe-Wang resin, $\mathrm{SnCl}_{2} / \mathrm{DMF}$ reduction $^{12}$ of the nitro group and HCTU/DIPEA coupling of the resulting amine with $N, N^{\prime}$-di-Boc-guanidinocarboxylic acid ${ }^{13}$ provided the protected guanidine 2 . Fmoc deprotection by $4-$ methylpiperidine furnished the common intermediate amine 3. The amine 3 was then coupled to a number of $N$-arylsulfonyl-Lproline analogues using HCTU/DIPEA, and final deprotection and cleavage from the resin with TFA provided the desired analogues 4-15.

Potency of each compound was then tested by performing cell adhesion assays mediated by $\alpha \mathrm{v} \beta 1$ integrin using $\alpha 5$ deficient $/ \alpha \mathrm{v}$ integrin engineered $\mathrm{CHO}$ cells as previously described (Table 1). ${ }^{6,14}$
Table 1. Cell Adhesion Assays of N-Arylsulfonyl Analogues $^{a, b, c}$

(1)

${ }^{a} \alpha 5$ integrin-deficient $/ \alpha \mathrm{v}$ integrin engineered $\mathrm{CHO}$ cell and fibronectin were used. Standard deviation $(n=3)$ was calculated for $\mathrm{pIC}_{50}{ }^{b} \mathrm{pIC}_{50}=-\operatorname{logIC} \mathrm{C}_{50}(\mathrm{M}) .{ }^{c}$ Native peptide fragment in fibronectin (GRGDS) showed a moderate $\mathrm{IC}_{50}($ ca. $100 \mu \mathrm{M})$.

It was found that any substitution on the phenyl ring generally decreased potency. In particular, 2- and/or 4- 
substitution on the phenyl ring $(4,6,8,9,13)$ significantly reduced inhibitory activity against $\alpha \mathrm{v} \beta 1$ integrin. This observation differs from our previously reported SAR study on $\alpha 2 \beta 1$ integrin inhibitors where 4-substitution on the phenyl ring was tolerable in the same $\mathrm{N}$-arylsulfonyl-L-proline scaffold. By contrast, 3-substitution $(7,10)$ and phenyl ring replacement by unsubstituted pyridine (11) or thiophene (12) allowed modestly retained potency against $\alpha \mathrm{v} \beta 1$ integrin, similar to results we previously reported for $\alpha 2 \beta 1 .^{8}$ Interestingly, dansyl group (14) also demonstrated retained potency, but the 4methyl substituted naphthylsulfonyl (15) markedly reduced potency. Further structural biology studies are needed to explain this difference, but it is likely that $N$-arylsulfonyl-Lproline moiety in $\alpha \mathrm{v} \beta 1$ and $\alpha 2 \beta 1$ integrin may sit in a different orientation. Molecular docking study of c6 in modeled $\alpha \mathrm{v} \beta 1$ integrin structure also suggested that phenyl sulfonyl ring is situated to allow a good shape complementarity (Figure 3). Thus, substitution on the phenyl ring might cause steric congestion in the pocket in the $\beta 1$ integrin.

We next turned our attention to the pyrrolidine ring, leaving the phenylsulfonyl group intact. The syntheses were accomplished either in solution or solid phase as described previously

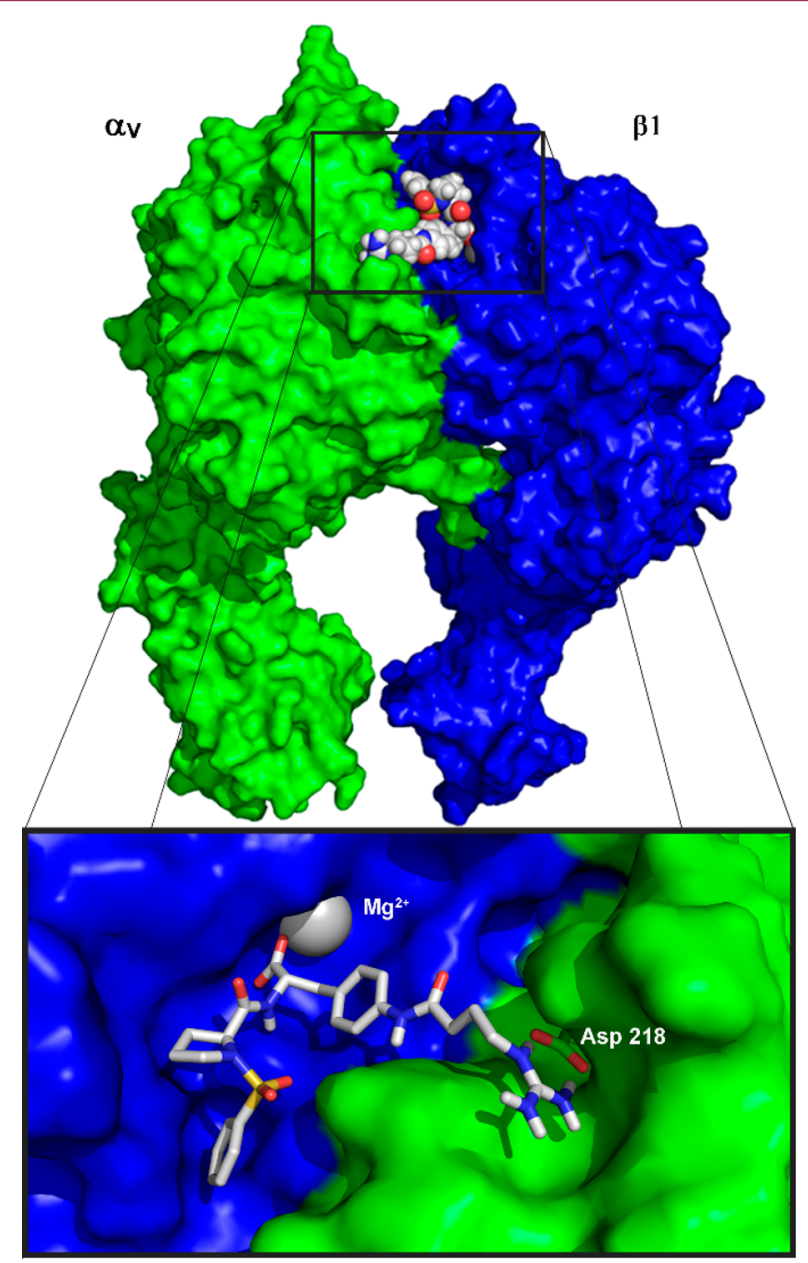

Figure 3. Molecular docking structure of c6 in modeled $\alpha \mathrm{v} \beta 1$ integrin. c6 binding region in $\alpha \mathrm{v} \beta 1$ integrin was shown in the rectangle. $\alpha \mathrm{v} \beta 1$ integrin structure was constructed by combination of the known $\alpha \mathrm{v} \beta 3$ (PDB code: $1 \mathrm{~L} 5 \mathrm{G})^{15}$ and $\alpha 5 \beta 1$ (PDB code: $\left.4 \mathrm{WK} 4\right)^{16}$ integrin structures. $\mathrm{Mg}^{2+}$ and Asp 218 were shown to indicate the key interactions with $\mathbf{c} 6$.
(Scheme 2). Briefly, dde (N-(1-(4,4-dimethyl-2,6dioxoeyclohexylidune)ethyl) protection ${ }^{17}$ of the amine in the

Scheme 2. Syntheses of $N$-Benzenesulfonyl-L-proline Analogues $^{a}$<smiles>COC(=O)[C@H](N)Cc1ccc([N+](=O)[O-])cc1</smiles><smiles>COC(=O)C(Cc1ccc(NC(=O)OC(C)(C)C)cc1)NC(=O)O[Na]</smiles>

4<smiles>CC(C)(C)NC(=N)Nc1ccc(CC(NC(=O)C2CCCCN2C(=O)C(C)(C)C)C(=O)O)cc1</smiles>

${ }^{a}$ Reagents and conditions: (a) (i) Dde-OH, DIPEA; (ii) $\mathrm{SnCl}_{2}$, EtOH, $60{ }^{\circ} \mathrm{C}$ (97\% over 2 steps); (b) Boc-aminovaleric acid $(n=4) /$ Boc-aminobutyric acid $(n=3)$, HCTU, DIPEA, DMF (quant.); (c) (i) TFA, DCM; (ii) N,N'-di-Boc-guanidino carboxylic acid, HCTU, DIPEA (56\% over 2 steps); (d) (i) $2.5 \%$ hydrazine, DMF; (ii) benzenesulfonyl proline analogues, HCTU, DIPEA; (iii) 50\% TFA/ DCM; (iv) $\mathrm{LiOH}$, THF- $\mathrm{H}_{2} \mathrm{O}$; (e) (i) $N$-benzenesulfonyl-L-proline analogues, HCTU, DIPEA; (ii) TFA/TIPS $/ \mathrm{H}_{2} \mathrm{O}$ (95:2.5:2.5).

commercially available 4-nitrophenylalanine methyl ester 16 yielded the compound 17 after reduction under $\mathrm{SnCl}_{2} / \mathrm{EtOH}$ condition of nitro group followed by coupling with $N, N^{\prime}$-diBoc-guanidinocarboxylic acids using HCTU/DIPEA. Dde protecting group was then removed by treatment with $2 \%$ hydrazine in DMF and coupled to N-benzenesulfonyl-L-proline analogues using HCTU/DIPEA. TFA deprotection of Boc group and hydrolysis of methyl ester provided the desired analogues 18-21 and 26. Alternatively, the analogues 22-25 were prepared by solid phase synthesis from compound 4 described above.

Potency of $\mathrm{N}$-benzenesulfonyl-L-proline analogues (18-26) seems to be affected by ring size and substitution (Table 2). For instance, azetidine (21) substitution dramatically lowered potency, which is in good agreement with our previous report in $\alpha 2 \beta 1$ integrin inhibitor design. However, 3,4-dehydroprolyl and unsubstituted or 3,3-dimethyl thiaprolyl ring (21-23) did not increase the potency, ${ }^{7}$ which is opposite to our observation in $\alpha 2 \beta 1$ integrin inhibitor series. This can be partially explained by the different binding mode of $N$-phenylsulfonyl-L-proline moiety between $\alpha 2 \beta 1$ and $\alpha \mathrm{v} \beta 1$ integrins. It is also noteworthy that no strong exo/endo conformational effect on the proline ring was observed. Both cis and trans isomer of 4-fluoro-Lproline $(\mathbf{2 4}, \mathbf{2 5})$ exhibited similar potency in cell adhesion assay. ${ }^{18}$ On the other hand, $\alpha$-methyl substitution $(26)$ and $\beta, \beta$ dimethyl substitution (23) almost completely abolished the inhibitory effect of c8 (for further comparison, see Supporting Information). ${ }^{7}$ While most $N$-arylsulfonyl-L-proline headgroup modifications failed to increase the potency, we did observe that piperidine replacement $(\mathbf{1 8}, \mathbf{1 9})$ showed slightly higher potency than $\mathbf{c 8}$. We speculate that pyrrolidine and piperidine share similar position conformations to locate the hydrophobic phenyl ring into the hydrophobic pocket (Figure 4). 
Table 2. Cell Adhesion Assays of N-Benzenesulfonyl-L-prolyl Analogues ${ }^{a, b, c}$

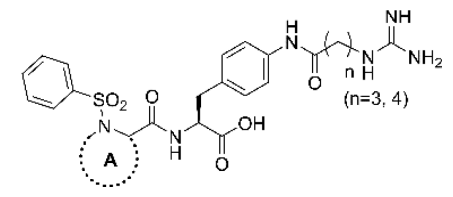

\begin{tabular}{|c|c|c|c|c|}
\hline & A & $\mathrm{n}$ & $\begin{array}{l}\text { av } \beta 1 \text { integrin } \\
\mathrm{IC} 50(\mathrm{nM})\end{array}$ & $\begin{array}{c}\alpha v \beta 1 \text { integrin } \\
\mathrm{pIC}_{50} \pm \mathrm{SD}\end{array}$ \\
\hline C8 & & 4 & 0.63 & $9.2 \pm 0.5$ \\
\hline C6 & & 3 & 0.02 & $10.7 \pm 0.1$ \\
\hline 18 & & 4 & 0.32 & $9.5 \pm 0.7$ \\
\hline 19 & & 3 & 0.25 & $9.6 \pm 0.6$ \\
\hline 20 & & 4 & 800 & $6.1 \pm 0.4$ \\
\hline 21 & & 4 & 160 & $6.8 \pm 0.8$ \\
\hline 22 & & 4 & 16 & $7.8 \pm 0.5$ \\
\hline 23 & & 4 & 2000 & $5.7 \pm 0.1$ \\
\hline 24 & & 4 & 0.5 & $9.3 \pm 0.7$ \\
\hline 25 & & 4 & 0.5 & $9.3 \pm 0.7$ \\
\hline 26 & & 4 & $>10000$ & $<5$ \\
\hline
\end{tabular}

${ }^{a} \alpha 5$ integrin-deficient $/ \alpha \mathrm{v}$ integrin-engineered $\mathrm{CHO}$ cell and fibronectin were used. ${ }^{b}$ Standard deviation $(n=3)$ was calculated for $\mathrm{pIC}_{50}$. ${ }^{c} \mathrm{pIC}_{50}=-\log \mathrm{IC}_{50}(\mathrm{M})$.

Next, we turned our attention to modification of the linker and guanidine groups in RGD mimetic moiety. We kept the original $\mathrm{N}$-benzenesulfonyl-L-proline headgroup intact since it turned out to be one of the most potent compounds. The syntheses of these analogues were performed using conventional solid-phase chemistry (Scheme 3). Starting from commercially available Fmoc-protected $p$-nitrophenylalanine on Wang resin, deprotection by 4-methylpiperidine (20\% in DMF) and amide bond formation with $N$-benzenesulfonyl-Lproline produced the common intermediate amine 27. Amide

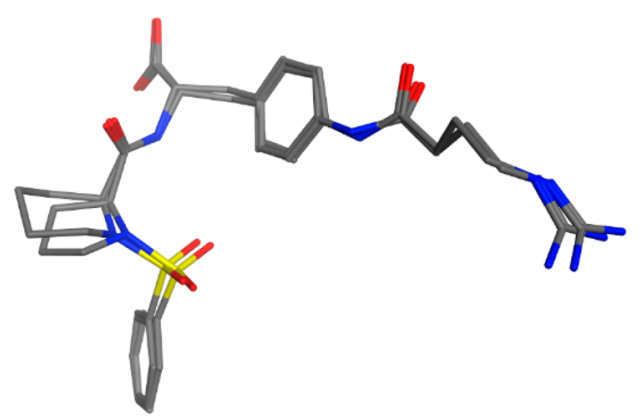

Figure 4. Overlay of docked structures of $c 6$ and piperidine analogue 19 in modeled $\alpha \mathrm{v} \beta 1$ integrin.

Scheme 3. Syntheses of Linker and Basic Unit Derivatives ${ }^{a}$<smiles>CCCC(C)(C)NC(Cc1ccc(N)cc1)C(=O)NC1CCCN1S(=O)(=O)c1ccccc1</smiles>

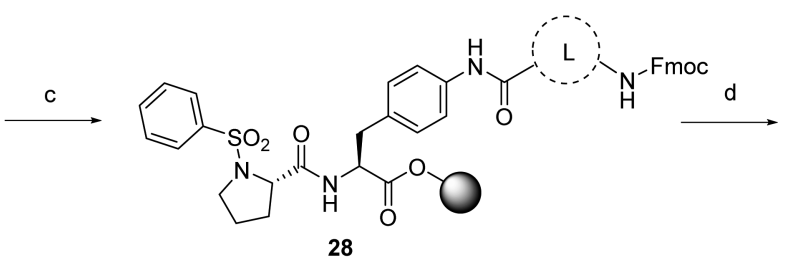<smiles>[R]NC1CCCC(C(=O)Nc2ccc(CC(NC(=O)[C@@H]3CCCN3C(=O)c3ccccc3)C(=O)O)cc2)CC1</smiles>

${ }^{a}$ Reagents and conditions: (a) (i) 4-methylpiperidine/DMF (1/4); (ii) N-benzenesulfonyl-L-proline, HCTU, DIPEA; (b) $\mathrm{SnCl}_{2}$, DMF, 60 ${ }^{\circ} \mathrm{C}$; (c) Fmoc-amino acids, HCTU, DIPEA, DMF; (d) (i) 4methylpiperidine/DMF (1:4); (ii) guanidylating agents, DIPEA or pyridine $\mathrm{N}$-oxides, PyBroP, DIPEA; (iii) TFA/TIPS $/ \mathrm{H}_{2} \mathrm{O}$ (95:2.5:2.5).

coupling with Fmoc amino acid derivatives and guanidylation of terminal amine after Fmoc deprotection produced the desired analogues 29-40 after final TFA cleavage from resin. For syntheses of 2-aminopyridine analogues (32-35), pyridine $\mathrm{N}$-oxide with PyBroP activation was particularly effective. ${ }^{19}$

From analysis of the cell adhesion results (Table 3), it was apparent that cyclic guanidines (29-31) can replace the original guanidine group in $\mathbf{c 8}$ with a similar or higher potency. However, high basicity of guanidine and cyclic guanidine could be problematic in further development due to their unfavorable pharmacokinetic properties. We were excited that aminopyridine replacement of guanidine was well tolerated. Indeed one of the aminopyridine analogues (33) showed a higher potency than $\mathbf{c 8}$. Furthermore, aminopyridine replacement not only reduces the charge due to its $\mathrm{p} K_{\mathrm{a}}$ (ca. 7), but also renders support on "side-on" binding pattern of basic group in $\alpha \mathrm{v} \beta 1$ integrin rather than "end-on" pattern as seen in $\alpha \mathrm{IIb} \beta 3$ integrin. ${ }^{20}$ 
Table 3. Cell Adhesion Assays of RGD Mimetic Analogues of $c 8^{a, b, c}$<smiles></smiles>

(CH2)

${ }^{a} \alpha 5$ integrin-deficient $/ \alpha \mathrm{v}$ integrin-engineered $\mathrm{CHO}$ cell and fibronectin were used. ${ }^{b}$ Standard deviation $(n=3)$ was calculated for $\mathrm{pIC}_{50}$. ${ }^{c} \mathrm{pIC}_{50}=-\log \mathrm{IC}_{50}(\mathrm{M})$.

Replacement of linear aliphatic linkers to rigid cyclic or aryl linkers also influences the potency. 3-Guanidino benzamide linker (37) showed 10-fold higher potency against $\alpha \mathrm{v} \beta 1$ integrin than $\mathbf{c 8}$, while 3-guanidino phenylacetamide linker (38) reduced the potency. Strikingly, almost no inhibition was observed in 4-guanidino benzamide linker (36). However, saturation of aromatic ring (39) regained the potency that suggests proper alignment of the basic group is key to maintain the potency. However, the bulky adamantyl linker (40) is seemingly ineffective.

Finally, selected potent compounds were tested on a panel of RGD integrins in cell adhesion assay as previously described (Table 4). ${ }^{6}$ All of the tested compounds $(18,19,29,33,37)$

Table 4. Selectivity of Selected N-Arylsulfonyl-L-prolyl Inhibitors $^{a, b, c}$

\begin{tabular}{rrrrrr} 
& \multicolumn{5}{c}{$\mathrm{IC}_{50}(\mathrm{nM})$} \\
\cline { 2 - 6 } $\mathbf{c 8}$ & $\alpha \mathrm{v} \beta 1$ & $\alpha \mathrm{v} \beta 3$ & $\alpha \mathrm{v} \beta 5$ & $\alpha \mathrm{v} \beta 8$ & $\alpha 5 \beta 1$ \\
18 & 0.63 & $>10000$ & $>10000$ & $>10000$ & $>10000$ \\
19 & 0.31 & 4000 & 160 & 2000 & 3200 \\
$\mathbf{2 9}$ & 0.25 & 2000 & 1600 & 2500 & 3200 \\
33 & 0.2 & $>10000$ & 200 & $>10000$ & $>10000$ \\
37 & 0.06 & 160 & $>10000$ & 400 & $>10000$ \\
& & $>10000$ & 40 & 63
\end{tabular}

${ }^{a}$ Cell adhesion mediated by $\alpha \mathrm{v} \beta 1, \alpha \mathrm{v} \beta 3, \alpha \mathrm{v} \beta 5, \alpha \mathrm{v} \beta 8$, and $\alpha 5 \beta 1$ was measured using pairs of cell lines and ligands selected to isolate the effect of each individual integrin: $\alpha \mathrm{v} \beta 1-\mathrm{CHO} \alpha \mathrm{v}$ ( $\alpha 5$-deficient $\mathrm{CHO}$ cells engineered to express $\alpha \mathrm{v} \beta 1)$ adhering to fibronectin $(0.3 \mathrm{mg} /$ $\mathrm{mL}), \alpha \mathrm{v} \beta 3-\mathrm{SW} 480$ cells transfected with human $\beta 3$ adhering to fibrinogen $(1 \mathrm{mg} / \mathrm{mL}), \alpha v \beta 5$-wild-type SW480 cells adhering to vitronectin $(0.1 \mathrm{mg} / \mathrm{mL}), \alpha \mathrm{v} \beta 8$-glioma cell line (SNB19) adhering to recombinant human TGF $\beta 1 \mathrm{LAP}(1 \mathrm{mg} / \mathrm{mL}), \alpha 5 \beta 1$-colon carcinoma cell line SW480 plated on fibronectin $(0.3 \mathrm{mg} / \mathrm{mL}) .{ }^{b}$ See Supporting Information for $\mathrm{pIC}_{50}$ and standard deviation $(n=3)$. ${ }^{c} \mathrm{pIC}_{50}=$ $-\log \mathrm{IC}_{50}(\mathrm{M})$.

showed a good to excellent selectivity against $\alpha \mathrm{v} \beta 1$ integrin over other RGD integrins. However, it should be noted that the selectivity diminished in 3-guanidino benzamide linker analogue (37), while homoproline analogue (19) was most selective.

In conclusion, we identified several highly potent $\alpha \mathrm{v} \beta 1$ integrin inhibitors by modification of $N$-arylsulfonyl-L-proline scaffold in c8. $\mathrm{N}$-Phenylsulfonyl-L-homoproline analogues were shown to be alternative candidates with excellent selectivity toward $\alpha \mathrm{v} \beta 1$ integrin over other RGD integrins. RGD-mimetic modification revealed cyclic guanidine and 2-aminopyridines are excellent basic groups. A 3-substituted benzamide linker showed the increased potency with a little diminished selectivity. Further medicinal chemistry efforts to obtain more potent and selective $\alpha \mathrm{v} \beta 1$ integrin inhibitors by combinations of these features are currently being made and will be reported in due course.

\section{ASSOCIATED CONTENT}

\section{Supporting Information}

The Supporting Information is available free of charge on the ACS Publications website at DOI: 10.1021/acsmedchemlett.6b00196.

Experimental details for syntheses of all new compounds and copies of ${ }^{1} \mathrm{H}$ and ${ }^{13} \mathrm{C}$ NMR spectra of key compounds 18, 19, 29, 33, and 37. $\mathrm{IC}_{50}$ curves of key compounds 18, 19, 29, 33, and 37 against $\alpha \mathrm{v} \beta 1$ integrin and $\mathrm{pIC}_{50}$ data for RGD integrins and $\mathrm{IC}_{50}$ comparison table between selected $\alpha \mathrm{v} \beta 1$ and $\alpha 2 \beta 1$ integrin inhibitors (PDF) 


\section{AUTHOR INFORMATION}

\section{Corresponding Author}

*E-mail: hyunil.jo@ucsf.edu.

\section{Author Contributions}

N.I.R. performed the biological assays. H.J., Y-Z.T., J.M., A.C., and W.F.D. designed the molecules and performed the chemical syntheses. H.J., J.M., Y.W, and K.S.M. collected and processed the NMR and high-resolution mass spectrometry data. H.J. and W.F.D. participated in molecular modeling and docking. D.S. and W.F.D. designed the study and supervised it. All the authors reviewed the final draft of the manuscript.

\section{Funding}

Research reported in this publication was supported by NHLBI of the National Institutes of Health under award number UH2HL123423. High-resolution mass spectrometry data was provided by the Bio-Organic Biomedical Mass Spectrometry Resource at UCSF (A.L. Burlingame, Director) supported by NIH NIGMS SP41GM103481.

\section{Notes}

The authors declare the following competing financial interest(s): H.J., N.I.R., Y-Z.T., D.S., and W.F.D. are inventors of a patent application related to this study.

\section{ACKNOWLEDGMENTS}

We would like to thank Dr. David Morgan, Jr. (Pliant Therapeutics) for helpful discussion in preparation of this manuscript. We also would like to thank Dr. Robert W. Newberry for proofreading and Dr. Mark Burlingame for highresolution mass spectrometry. Y-Z.T. (No.201307630010) thanks the scholarship from China Scholarship Council (CSC). We also acknowledge support for the Central California $900 \mathrm{MHz}$ NMR facility through grant GM68933 from the National Institutes of Health.

\section{ABBREVIATIONS}

DMF, dimethylformamide; HCTU, O-(6-chlorobenzotriazol-1-

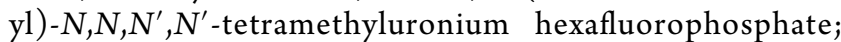
DIPEA, N,N-diisopropylethylamine; TIPS, triisopropylsilane; TFA, trifluoroacetic acid; Dde, N-(1-(4,4-dimethyl-2,6dioxoeyclohexylidune)ethyl; DCM, dichloromethane; PyBroP, bromotripyrrolidinophosphonium hexafluorophosphate

\section{REFERENCES}

(1) Hynes, R. O. Integrins: versatility, modulation, and signaling in cell adhesion. Cell 1992, 69, 11-25.

(2) Hynes, R. O. Integrins: bidirectional, allosteric signaling machines. Cell 2002, 110, 673-687.

(3) Goodman, S. L.; Picard, M. Integrins as therapeutic targets. Trends Pharmacol. Sci. 2012, 33, 405-412.

(4) Spagnolo, P.; Wells, A. U.; Collard, H. R. Pharmacological treatment of idiopathic pulmonary fibrosis: an update. Drug Discovery Today 2015, 20, 514-524.

(5) Henderson, N. C.; Arnold, T. D.; Katamura, Y.; Giacomini, M. M.; Rodriguez, J. D.; McCarty, J. H.; Pellicoro, A.; Raschperger, E.; Betsholtz, C.; Ruminski, P. G.; Griggs, D. W.; Prinsen, M. J.; Maher, J. J.; Iredale, J. P.; Lacy-Hulbert, A.; Adams, R. H.; Sheppard, D. Targeting of alphav integrin identifies a core molecular pathway that regulates fibrosis in several organs. Nat. Med. 2013, 19, 1617-1624.

(6) Reed, N. I.; Jo, H.; Chen, C.; Tsujino, K.; Arnold, T. D.; DeGrado, W. F.; Sheppard, D. The alphavbetal integrin plays a critical in vivo role in tissue fibrosis. Sci. Transl. Med. 2015, 7, 288ra279.

(7) Miller, M. W.; Basra, S.; Kulp, D. W.; Billings, P. C.; Choi, S.; Beavers, M. P.; McCarty, O. J.; Zou, Z.; Kahn, M. L.; Bennett, J. S.;
DeGrado, W. F. Small-molecule inhibitors of integrin alpha2beta1 that prevent pathological thrombus formation via an allosteric mechanism. Proc. Natl. Acad. Sci. U. S. A. 2009, 106, 719-724.

(8) Choi, S.; Vilaire, G.; Marcinkiewicz, C.; Winkler, J. D.; Bennett, J. S.; DeGrado, W. F. Small molecule inhibitors of integrin alpha2beta1. J. Med. Chem. 2007, 50, 5457-5462.

(9) Hagmann, W. K.; Durette, P. L.; Lanza, T.; Kevin, N. J.; de Laszlo, S. E.; Kopka, I. E.; Young, D.; Magriotis, P. A.; Li, B.; Lin, L. S.; Yang, G.; Kamenecka, T.; Chang, L. L.; Wilson, J.; MacCoss, M.; Mills, S. G.; Van Riper, G.; McCauley, E.; Egger, L. A.; Kidambi, U.; Lyons, K.; Vincent, S.; Stearns, R.; Colletti, A.; Teffera, J.; Tong, S.; FenykMelody, J.; Owens, K.; Levorse, D.; Kim, P.; Schmidt, J. A.; Mumford, R. A. The discovery of sulfonylated dipeptides as potent VLA-4 antagonists. Bioorg. Med. Chem. Lett. 2001, 11, 2709-2713.

(10) Doherty, G. A.; Yang, G. X.; Borges, E.; Tong, S.; McCauley, E. D.; Treonz, K. M.; Van Riper, G.; Pacholok, S.; Si, Q.; Koo, G. C.; Shah, K.; Mumford, R. A.; Hagmann, W. K. N-isonicotinoyl-(L)-4aminophenylalanine derivatives as tight binding VLA-4 antagonists. Bioorg. Med. Chem. Lett. 2003, 13, 1891-1895.

(11) Lin, L. S.; Lanza, T.; McCauley, E.; Van Riper, G.; Kidambi, U.; Cao, J.; Egger, L. A.; Mumford, R. A.; Schmidt, J. A.; MacCoss, M.; Hagmann, W. K. Specific and dual antagonists of alpha(4)beta(1) and alpha(4)beta(7) integrins. Bioorg. Med. Chem. Lett. 2002, 12, 133-136.

(12) Corbett, J. W.; Graciani, N. R.; Mousa, S. A.; DeGrado, W. F. Solid-phase synthesis of a selective alpha(v)beta(3) integrin antagonist library. Bioorg. Med. Chem. Lett. 1997, 7, 1371-1376.

(13) Costanzo, M. J.; Yabut, S. C.; Almond, H. R., Jr.; AndradeGordon, P.; Corcoran, T. W.; De Garavilla, L.; Kauffman, J. A.; Abraham, W. M.; Recacha, R.; Chattopadhyay, D.; Maryanoff, B. E. Potent, small-molecule inhibitors of human mast cell tryptase. Antiasthmatic action of a dipeptide-based transition-state analogue containing a benzothiazole ketone. J. Med. Chem. 2003, 46, 38653876.

(14) Zhang, Z.; Morla, A. O.; Vuori, K.; Bauer, J. S.; Juliano, R. L.; Ruoslahti, E. The alpha $\mathrm{v}$ beta 1 integrin functions as a fibronectin receptor but does not support fibronectin matrix assembly and cell migration on fibronectin. J. Cell Biol. 1993, 122, 235-242.

(15) Xiong, J. P.; Stehle, T.; Zhang, R.; Joachimiak, A.; Frech, M.; Goodman, S. L.; Arnaout, M. A. Crystal structure of the extracellular segment of integrin alpha Vbeta3 in complex with an Arg-Gly-Asp ligand. Science 2002, 296, 151-155.

(16) Xia, W.; Springer, T. A. Metal ion and ligand binding of integrin alpha 5 beta 1. Proc. Natl. Acad. Sci. U. S. A. 2014, 111, 17863-17868.

(17) Zhang, L.; Lee, H. K.; Pruess, T. H.; White, H. S.; Bulaj, G. Synthesis and applications of polyamine amino acid residues: improving the bioactivity of an analgesic neuropeptide, neurotensin. J. Med. Chem. 2009, 52, 1514-1517.

(18) DeRider, M. L.; Wilkens, S. J.; Waddell, M. J.; Bretscher, L. E.; Weinhold, F.; Raines, R. T.; Markley, J. L. Collagen stability: insights from NMR spectroscopic and hybrid density functional computational investigations of the effect of electronegative substituents on prolyl ring conformations. J. Am. Chem. Soc. 2002, 124, 2497-2505.

(19) Londregan, A. T.; Jennings, S.; Wei, L. General and mild preparation of 2-aminopyridines. Org. Lett. 2010, 12, 5254-5257.

(20) Delouvrie, B.; Al-Kadhimi, K.; Arnould, J. C.; Barry, S. T.; Cross, D. A.; Didelot, M.; Gavine, P. R.; Germain, H.; Harris, C. S.; Hughes, A. M.; Jude, D. A.; Kendrew, J.; Lambert-van der Brempt, C.; Lohmann, J. J.; Menard, M.; Mortlock, A. A.; Pass, M.; Rooney, C.; Vautier, M.; Vincent, J. L.; Warin, N. Structure-activity relationship of a series of non peptidic RGD integrin antagonists targeting alpha5beta1: part 2. Bioorg. Med. Chem. Lett. 2012, 22, 4117-4121. 